\title{
ОСОБЕННОСТИ СТАНОВЛЕНИЯ И РАЗВИТИЯ ТЕХНОПАРКОВЫХ СТРУКТУР В РОССИЙСКОЙ ФЕДЕРАЦИИ
}

\author{
(c) 2020 Вологдина Елена Сергеевна \\ студент магистратуры, Факультет экономики и менеджмента, \\ Кафедра экономики, финансов и бухгалтерского учета \\ Комсомольский-на-Амуре государственный университет, Россия, Комсомольск-на-Амуре \\ E-mail: vologdina-el@yandex.ru
}

(c) 2020 Кизиль Елена Витальевна

доктор экономических наук, профессор кафедры экономики, финансов и бухгалтерского учёта

Комсомольский-на-Амуре государственный университет, Россия, Комсомольск-на-Амуре

E-mail:kisil_ev@mail.ru

В работе рассмотрено значение технопарковых структур для экономики страны. На основе статистических данных анализируется динамика развития технопарков в Российской Федерации. Акцентировано внимание на трудностях в создании и функционировании университетских технопарков как структурных подразделений высших учебных заведений.

Ключевые слова: технопарковые структуры, динамика развития технопарков, трудности становления университетских технопарков.

Согласно общепризнанному мнению, технопарковые структуры являются действенным инструментом восстановления экономик кризисных регионов, нуждающихся в развитии новых типов производств и технологий, поиске эффективных способов инвестирования. Не случайно это изобретение научно-технической мысли активно использовалось в кризисные для Европы 80-е годы. Россия встала на инновационный путь развития с использованием технопарковых структур только с 2006 года [2].

По определению Семеновой А.Е., «технопарк является компактным комплексом, включающим в себя научные учреждения, вузы и предприятия промышленности» [5, с. 83]. Его деятельность основана на принципах предпринимательства и трансфера инноваций в сферу материального производства.

В 2018 году функционировало 43 промышленных кластера в 32 субъектах Российской Федерации и 157 технопарков в 53 регионах [4].

Анализ динамики развития технопарков в России показывает, что с 2014 по 2018 гг. их количество увеличилось более чем на $120 \%$, а число регионов, где они представлены,- на $77 \%$. Увеличение количества промышленных кластеров с 2016 по 2018 гг. составил более 200\% [4]. Таким образом, положительные тенденции роста числа кластеров и технопарков очевидны.

Начиная с 2019 года, осуществляется госу-

дарственная поддержка создания технопарков для развития малого и среднего предпринимательства (МСП) в рамках Национального проекта «МСП и поддержка индивидуальной предпринимательской инициативы», оператором которой является Минэкономразвития России.

С помощью государственного финансирования в объеме 4,5 млрд. рублей в 2019 году было введено в строй 22 технопарка в 16 регионах страны. В 2020 году планируется увеличить объем государственной поддержки до 5,9 млрд. рублей в год, при этом ожидается, что количество проектов возрастёт ещё на 17 единиц. За весь срок реализации нацпроекта по поддержке МСП (до 2024 года), согласно Паспорту программы, на цели развития технопарковых структур выделено 30 млрд. рублей [6].

Согласно национальному рейтингу технопарков, публикуемому Ассоциацией кластеров и технопарков России, размещение технопарковых структур по территории Российской Федерации характеризуется крайней неравномерностью (рисунок). Основная их часть, причем имеющая тенденцию к росту, сконцентрирована в наиболее экономически развитом Центральном Федеральном округе (города Москва, СанктПетербург, Московская область). Удельный вес технопарков с 2014 г по 2018 г. увеличился на 9\% и составил к 2018 году 55\% от общего количества технопарковых структур в России. 


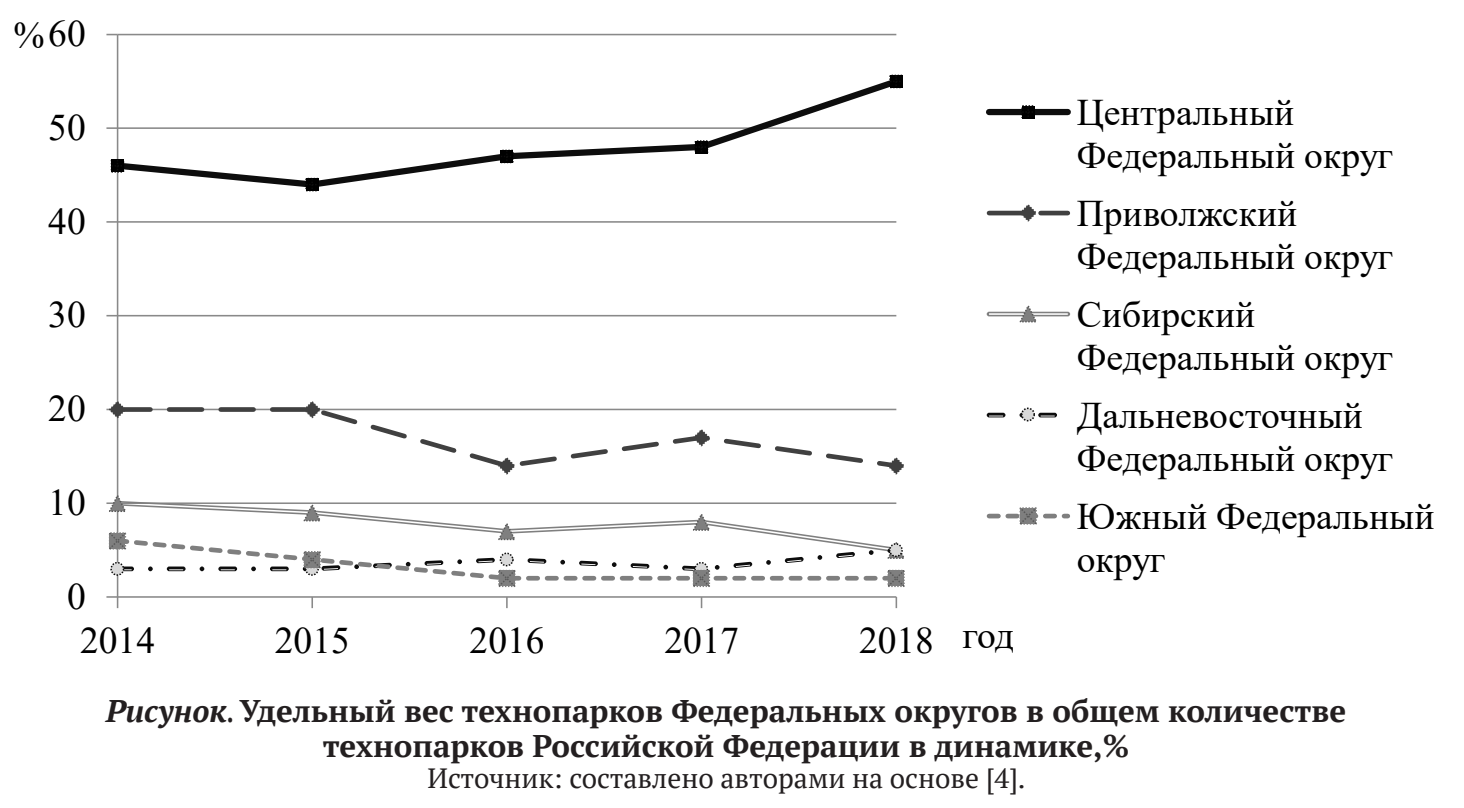

Второе место занимает Приволжский Федеральный округ (Республика Татарстан, Республика Мордовия, Нижегородская, Самарская, Ульяновская области), доля технопарков в котором в общем числе технопарков страны варьируется от $20 \%$ в 2014 г. до 14\% в 2018 г.

Аутсайдерами рейтинга являются Дальневосточный Федеральный округ (ДФО) и Южный Федеральный округ (ЮФО), в которых технопарков насчитываются единицы. Так, в ДФО доля технопарков достигла 5\% только к 2018 году, а в ЮФО она снизилась с 6\% в 2014 г. до 2\% в 2018 г.

Территориальная неравномерность в распределении технопарков и их наличие в том или ином субъекте Российской Федерации определяются не только близостью к крупным финансовым, научным центрам и академической среде, но и, по большей части, заинтересованностью частных инвесторов и региональных органов государственной власти в развитии новых высокотехнологичных видов экономической деятельности.

В основном технопарки создаются и функционируют на базе структурных подразделений высших учебных заведений. Так, на территории Дальневосточного федерального округа (ДВФО) среди организаций, имеющих технопарковые образования, восемь - это структурные подразделения вузов (таблица).

Следует подчеркнуть, что анализ отечественных исследований в области развития университетских российских технопарков показал наличие существенных негативных моментов в

их организации и функционировании [3].

На наш взгляд, первопричина недостаточно активного процесса «технопарковизации» страны - отсутствие инициативы снизу, то есть, отечественные университеты не были инициаторами создания технопарков. Это решение, продиктованное сверху, основывалось не на экономической необходимости, а базировалось на желании не отстать от зарубежных партнеров.

У подавляющего числа технопарков страны отсутствует статус юридического лица. Как правило, они являются структурными подразделениями вузов. Учебное заведение подчас становится единственным учредителем технопарка, что ограничивает его технические возможности, сужает материально-техническую базу производства инновационной продукции.

Не будучи самодостаточными структурами в финансовом плане, технопарки зависимы от бюджетных ассигнований и становятся еще одной статьей расхода для вуза, а не дополнительным источником дохода.

Современные тенденции развития образовательной отрасли ориентируют вуз на многоцелевое позиционирование его функционирования: одновременно с подготовкой кадров, как основной функцией учебного заведения, высшая школа должна активно включаться в процесс получения прибыли от новаторской деятельности посредством технопарков. Но российские вузы, как экономические субъекты, не имеют большого опыта в предпринимательской сфере. У преподавателей и студентов отсутствуют навыки 
Таблица. Высшие учебные заведения ДВФО, имеющие технопарковые структуры

\begin{tabular}{|c|c|}
\hline Субъекты РФ ДВФО & Высшие учебные заведения ДВФО \\
\hline Хабаровский край & $\begin{array}{l}\text { ФГБОУ ВО «Комсомольский-на-Амуре государственный университет» ((Техно- } \\
\text { парк, Центр коллективного пользования, Инжиниринговый центр); ФГБОУ ВО } \\
\text { «Тихоокеанский государственный университет» (бизнес-инкубатор), ФГБОУ ВО } \\
\text { «Дальневосточный государственный университет путей сообения» (молодежный } \\
\text { бизнес-инкубатор) }\end{array}$ \\
\hline Приморский край & $\begin{array}{l}\text { ФГАОУ ВО «Дальневосточный федеральный университет» (Центр коллективного } \\
\text { пользования, Технопарк «Русский», Акселератор, Кластер технологического пред- } \\
\text { принимательства, в том числе Центр проектной деятельности, Бизнес Инкубатора } \\
\text { «Теrra Creativa», Фонд ДВФУ, Фонд поддержки технологического предпринима- } \\
\text { тельства ДВФУ); ФГБОУ ВО «Владивостокский государственный университет } \\
\text { экономики и сервиса» ((Инновационный бизнес-инкубатор, Fab-lab); ФГБОУ Во } \\
\text { «Дальневосточный государственный технический рыбохозяйственный универси- } \\
\text { тет» (Центр инновационных технологий) }\end{array}$ \\
\hline $\begin{array}{l}\text { Республика Саха (Яку- } \\
\text { тия) }\end{array}$ & $\begin{array}{l}\text { ФГАОУ ВО «Северо-Восточный федеральный университет имени М.К. Аммосова» } \\
\text { (Арктический инновационный центр: Центр интеллектуальной собственности, } \\
\text { Центр маркетинга инноваций и управления проектами, Центр коллективного } \\
\text { пользования, Сектор юридического сопровождения инновационной деятельности, } \\
\text { студенческий бизнес-инкубатор «ОRЕН») }\end{array}$ \\
\hline Сахалинская область & $\begin{array}{l}\text { ФГБОУ ВО «Сахалинский государственный университет» (Биотехнопарк «Сахалин- } \\
\text { ский», Центр поддержки технологий и инноваций) }\end{array}$ \\
\hline
\end{tabular}

Источник: составлено авторами с использованием [1]

ведения инновационного бизнеса.

Кроме того, сложившаяся практика, когда практически единственными участниками университетских технопарков становятся преподаватели этого же вуза, не склонные менять место работы, препятствует процессу ротации малых инновационных фирм, поддержке новых и перспективных компаний. Добавим сюда слабые связи вузов, как структур федерального подчинения, с региональными и местными властями, а также отсутствие квалифицированного менеджмента управляющих компаний, не способных эффективно организовать работу университетских технопарков.

В заключение следует отметить, что создание технопарков в Российской Федерации сопровождается процессом неравномерной территориальной концентрации финансовых и интеллектуальных ресурсов, поэтому условий для ускорения развития высокотехнологичных отраслей экономики в масштабах всей страны недостаточно.

Существует немало проблем в развитии университетских технопарков, которые не дают им возможность стать локомотивами инновационных преобразований региональной экономики. Первый опыт создания технопарковых структур на базе вузов по образу зарубежных моделей оказался негативным (слабая связь с вузовской наукой и образовательным процессом, нерешенные проблемы использования вузовской интеллектуальной собственности и т.д.). Тем не менее, теоретизация вопросов деятельности технопарков и анализ сравнительно небольшого практического опыта их функционирования в Российской Федерации позволяют говорить о возможности их положительного влияния на развитие инновационной инфраструктуры регионов. Укрепление научного потенциала страны способствует росту малых инновационных предприятий. Университетские технопарки можно рассматривать как одну из эффективных основ их поддержки. И если данная форма предпринимательской деятельности сможет определить вектор развития российской экономики, то за технопарковыми структурами стоит большое будущее.

\section{Библиографический список}

1. Ефременко, В.Ф. Динамика развития инновационной инфраструктуры в региональных инновационных системах Дальневосточного федерального округа Российской Федерации / В.Ф. Ефременко, С. М. Бахарев // Власть и управление на Востоке России. - 2019. - № 1 (86). - С. 41-50.

2. Масленникова, А.Д. Российские технопарковые структуры: история, проблемы, перспективы развития / А.Д. Масленникова // Молодежный научный вестник. - 2018. - № 5. - С. 380-383. 
3. Павель, Е.В. Роль технопарковых структур университета в инновационном развитии региона / Е.В. Павель, Т.В. Кудряшова // Вестник института экономики и управления НОВГУ. - 2018. - № 4(29). - С. 75-84.

4. Проблемы и перспективы развития кластеров и технопарков в России [Электронный ресурс]: официальный сайт «Ассоциация кластеров и технопарков России».- Режим доступа: http:/www.akitrf.ru/presscenter/publikacii-v-smi/problemy-i-perspektivy-razvitiya-klasterov-i-tekh noparkov-v-rossii/ (дата обращения: 03.03.2020).

5. Семенова, А.Е. Роль технопарковой структуры в развитии инновационного предпринимательства / А.Е. Семенова // Инновационные технологии в науке и образовании: сборник статей V Международной научнопрактической конференции.-Пенза: Наука и просвещение, 2017.- С. 83-85.

6. Технопарки. Технограды. Техножизнь [Электронный ресурс]: Национальный онлайн-портал для предпринимателей Мойбизнесс.рф.- Режим доступа: https://xn-90aifddrld7a.xn-p1ai/novosti/news/tekhnoparkitekhnogrady-tekhnozhizn (дата обращения: 03.03.2020). 